\title{
The Interaction of Hemin, a Porphyrin Derivative, with the Purified Rat Brain 2-Oxoglutarate Carrier
}

\author{
Daniela Valeria Miniero ${ }^{1, *,+(\mathbb{D}, \text { Anna Spagnoletta }}{ }^{2,+} \mathbb{C}$, Nicola Gambacorta $^{3}$, Vito Scalera ${ }^{1}$, \\ Ciro Leonardo Pierri ${ }^{1,4}$ (D), Orazio Nicolotti ${ }^{3}$ (D) and Annalisa De Palma ${ }^{1, *(D)}$ \\ 1 Department of Biosciences, Biotechnologies, and Biopharmaceutics, University "Aldo Moro" of Bari, \\ Via E. Orabona, 4, I-70125 Bari, Italy; vito.scalera@uniba.it (V.S.); ciro.pierri@uniba.it (C.L.P.) \\ 2 ENEA Italian National Agency for New Technologies, Energy and Sustainable Economic Development, \\ Trisaia Research Centre, S.S. 106 Jonica, Km 419,500, I-75026 Rotondella, Italy; anna.spagnoletta@enea.it \\ 3 Dipartimento di Farmacia-Scienze del Farmaco, Università degli Studi di Bari "Aldo Moro", \\ Via E. Orabona, 4, I-70125 Bari, Italy; nicola.gambacorta1@uniba.it (N.G.); orazio.nicolotti@uniba.it (O.N.) \\ 4 BROWSer S.r.l. c/o, University “Aldo Moro" of Bari, Via E. Orabona, 4, I-70125 Bari, Italy \\ * Correspondence: danielavaleria.miniero@uniba.it (D.V.M.); annalisa.depalma@uniba.it (A.D.P.) \\ + These authors contributed equally.
}

Citation: Miniero, D.V.; Spagnoletta, A.; Gambacorta, N.; Scalera, V.; Pierri, C.L.; Nicolotti, O.; De Palma, A. The Interaction of Hemin, a Porphyrin Derivative, with the Purified Rat Brain 2-Oxoglutarate Carrier. Biomolecules 2021, 11, 1175. https:// doi.org/10.3390/biom11081175

Academic Editor: Mathias O. Senge

Received: 10 June 2021

Accepted: 3 August 2021

Published: 9 August 2021

Publisher's Note: MDPI stays neutral with regard to jurisdictional claims in published maps and institutional affiliations.

Copyright: (c) 2021 by the authors. Licensee MDPI, Basel, Switzerland. This article is an open access article distributed under the terms and conditions of the Creative Commons Attribution (CC BY) license (https:// creativecommons.org/licenses/by/ $4.0 /)$.

\begin{abstract}
The mitochondrial 2-oxoglutarate carrier (OGC), isolated and purified from rat brain mitochondria, was reconstituted into proteoliposomes to study the interaction with hemin, a porphyrin derivative, which may result from the breakdown of heme-containing proteins and plays a key role in several metabolic pathways. By kinetic approaches, on the basis of the single binding centre gated pore mechanism, we analyzed the effect of hemin on the transport rate of OGC in uptake and efflux experiments in proteoliposomes reconstituted in the presence of the substrate 2-oxoglutarate. Overall, our experimental data fit the hypothesis that hemin operates a competitive inhibition in the $0.5-10 \mu \mathrm{M}$ concentration range. As a consequence of the OGC inhibition, the malate/aspartate shuttle might be impaired, causing an alteration of mitochondrial function. Hence, considering that the metabolism of porphyrins implies both cytoplasmic and mitochondrial processes, OGC may participate in the regulation of porphyrin derivatives availability and the related metabolic pathways that depend on them (such as oxidative phosphorylation and apoptosis). For the sake of clarity, a simplified model based on induced-fit molecular docking supported the in vitro transport assays findings that hemin was as good as 2-oxoglutarate to bind the carrier by engaging specific ionic hydrogen bond interactions with a number of key residues known for participating in the similarly located mitochondrial carrier substrate binding site.
\end{abstract}

Keywords: mitochondrial carrier; kinetic study; inhibition; single binding centre gated pore mechanism; porphyrin derivatives; induced-fit molecular docking

\section{Introduction}

Heme is an endogenous porphyrin essential for several biological processes of aerobic cells, such as the transport and storage of oxygen, signal transduction mechanisms and structural components of hemeproteins. Heme-like derivatives play a crucial function in oxidative phosphorylation and oxygen consumption [1,2]. Biosynthesis of heme is a multistep process between the mitochondria and cytosol that involves condensation between glycine and succinyl-CoA to form 5-aminolevulinate in the mitochondria, catalyzed by $\delta$-aminolevulinate synthase 2 (ALAS2) [3-5]. Following its synthesis, 5-aminolevulinate is transported to the cytosol where it leads to a series of reactions that culminate in the formation of co-protoporphyrinogen III [3-5]. Then, it re-enters the mitochondria where it is decarboxylated and oxidized to protoporphyrin IX, which incorporates ferrous iron by the reaction catalyzed by ferrochelatase to form heme [6-9]. Therefore, a tight regulation of the presence of its precursors and heme itself into the intermembrane space and into the 
mitochondrial matrix might be crucial for heme prosthetic group biosynthesis, as well as for the assembly of heme proteins.

Although all the enzymatic steps leading to the production of heme are well characterized [5-9], the mechanism of mitochondrial heme homeostasis is not yet clear. Transport of porphyrins in the isolated mitochondria is energy-dependent, as expected for the movement of anions into a negatively charged environment [10-12]. Protoporphyrin IX is slightly negatively charged at physiological $\mathrm{pH}$ and an anion of this size would not penetrate the inner mitochondrial membrane unless mediated by some mechanism(s) other than passive diffusion. Deuteroporphyrin IX [9] as well as protoporphyrin IX [11] have been shown to be accumulated in the mitochondria by a carrier-mediated transport-like mechanism.

Recently, some studies have highlighted the involvement of mitochondrial carriers in the accumulation of porphyrin derivatives into mitochondria $[13,14]$. Interestingly, the 2-oxoglutarate carrier (OGC) and the adenine nucleotide translocator (ANT), members of the mitochondrial carrier family located into the inner mitochondrial membrane $[15,16]$, are able to bind some porphyrin derivatives with a crucial role in heme biosynthesis and their functions appear to be related to the accumulation of heme precursors into the mitochondrial matrix $[13,14]$.

Among porphyrin derivatives playing a role in mitochondrial metabolism, hemin is one of the most studied molecules due to its ability in regulating mitochondrial function as a single molecule or in combination with other small molecules [17-19]. It was also reported that hemin may be released from hemoglobin as a consequence of central nervous system (CNS) hemorrhage and is present at high micromolar concentrations in intracranial hematomas [20]. Although hemin's real protective/dangerous effects on mitochondrial function are still a matter of debate, it is known that free hemin in mammals can exert a neuroprotective effect with the expression of neuroglobin ( $\mathrm{Ngb}$ ) [21], and it also appears to be able to trigger or prevent mitochondrial dysfunction, depending on the targeted pathways in different tissues $[17,18]$. Hemin also shows regulatory functions such as the repression of nonspecific $\delta$-aminolevulinate synthase expression [22], and can stimulate growth of oral bacteria, acting as an indicator of possible pathological conditions [23]. Hemin therapy has already been demonstrated to be effective in the treatment of hemedeficiency-related disorders such as porphyria [24]. It should be noticed that free hemin might also result from the breakdown of hemin-containing proteins highlighted in several microorganisms, such as Porphyromonas gingivalis [25] or Bartonella henselae [26].

At the mitochondrial level, it is known that hemin induces the activity of heme oxygenase, preventing alterations or reducing oxidative stress. It seems likely that the antioxidant effects associated with heme oxygenase upregulation are responsible for both the protective effect of hemin administration on mitochondrial function and its action to prevent protein oxidation/lipid peroxidation $[17,18]$.

Given the role played by hemin in regulating redox homeostasis, the ability of OGC in binding heme-like molecules [27] and the involvement of OGC in maintaining redox homeostasis through its participation in the malate/aspartate shuttle [28], we try to ascertain if OGC can bind hemin.

As a mitochondrial transporter, OGC is an antiporter and transports through the mitochondrial inner membrane the 2-oxoglutarate coming from the cytosol into mitochondria via an electroneutral exchange for malate from the mitochondrial matrix [29-32]. OGC is very important for several metabolic reactions, including the citric acid cycle, gluconeogenesis and nitrogen metabolism, beyond the transfer of reducing equivalents through the malate/aspartate shuttle [33,34].

From a structural point of view, OGC, as a member of mitochondrial carriers, shows a tripartite structure, thus consisting of three tandem-repeated sequences of about 100 amino acids in length [29-34]. Each repeat contains two hydrophobic stretches that span the inner mitochondrial membrane as $\alpha$-helices and a characteristic sequence motif consisting of residues P-X-D/E-XX-K/R-(20-30 residues)-EG-XXXXX-Aromatic residue-K/R-G linking 
the two helices of each repeat, entirely conserved in all the members of the mitochondrial carrier family, also through phylogenetically distant species [35-42].

The OGC carrier has been studied by site-directed mutagenesis [43-45]; it has been purified from various sources [46] and the characterization of the transport mechanism has been reported [30-32,47]. The OGC from rat brain mitochondria, reconstituted into proteoliposomes, was studied by kinetic approaches, reaching the conclusion that the carrier can swap its substrates according to the single binding centre gated pore mechanism. Based on this mechanism, a single binding site is alternatively accessible from the matrix or the cytosol, as demonstrated for the ADP/ATP carrier, tricarboxylate carrier and the OGC, modifying the employed equations for the presence of a further ligand $[16,48,49]$. Herein, we have examined the influence of a porphyrin derivative, namely hemin, on the transport of labeled substrates mediated by the reconstituted OGC, isolated from rat brain mitochondria in order to gain more direct information about its ability to bind OGC and/or behave as a modulator of OGC function.

\section{Materials and Methods}

\subsection{Chemicals}

In regards to chemicals: $\left[{ }^{14} \mathrm{C}\right]$ 2-oxoglutarate and $\left[{ }^{14} \mathrm{C}\right]$ malate were purchased from Perkin-Elmer Life Sciences; hydroxylapatite (Bio-gel HTP) and Amberlite Bio-Beads SM-2 from Bio-Rad; Triton X-100, Triton X-114, acrylamide and $N, N^{\prime}$-methylenebisacrylamide from Serva; egg yolk phospholipids from Fluka; Matrex Gel Orange from Amicon (Beverly, MA, USA); hemin, cardiolipin, 1,4-piperazine-diethanesulphonicacid (Pipes), sodium dodecyl sulfate (SDS) and asolectin from Sigma; celite 535 from Roth and Sephadex G-75 from Pharmacia. All other chemicals used were of analytical grade.

\subsection{Purification of the OGC Carrier}

The 2-oxoglutarate carrier was purified from rat brain mitochondria according to a protocol described in [48]. Briefly, mitochondria were solubilized with a solution containing $3 \%$ Triton X-100 $(w / v), 20 \mathrm{mM} \mathrm{Na} \mathrm{SO}_{4}, 1 \mathrm{mM}$ EDTA and $10 \mathrm{mM}$ Pipes, $\mathrm{pH} 7.0$ at a final protein concentration of $10 \mathrm{mg} / \mathrm{mL}$. After the incubation at $4{ }^{\circ} \mathrm{C}$ for $10 \mathrm{~min}$, the mixture was supplemented with $4 \mathrm{mg} / \mathrm{mL}$ of cardiolipin and centrifuged at $15,000 \times \mathrm{g}$ for $15 \mathrm{~min}$. After, the supernatant was applied to about $0.6 \mathrm{~g}$ of cold hydroxylapatite/celite (5:1) columns and eluted in the presence of $3 \%$ Triton X-100 $(w / v)$. The first $0.6 \mathrm{~mL}$ fraction was collected and applied on a cold Matrex Gel Orange column pre-equilibrated with $4 \mathrm{~mL}$ of $0.1 \%$ Triton $\mathrm{X}-100(w / v)$ in the presence of $10 \mathrm{mM} \mathrm{Na}_{2} \mathrm{SO}_{4}, 1 \mathrm{mM}$ EDTA and $5 \mathrm{mM}$ Pipes, $\mathrm{pH} 7.0$ with added $2 \mathrm{mg} / \mathrm{mL}$ asolectin. Fractions of $0.8 \mathrm{~mL}$ were collected and pure OGC was present in the second fraction with an apparent molecular weight of $35 \mathrm{kDa}$ [48]. All the operations were performed at $4{ }^{\circ} \mathrm{C}$.

\subsection{Reconstitution of the OGC into Liposomes}

Purified OGC was reconstituted into liposomes by removing the detergent using a micro-batchwise method in the presence of ion-exchange resin Bio-Beads SM-2 as described in ref. [50]. The initial mixture used for reconstitution was constituted by $200 \mu \mathrm{L}$ of the purified OGC, $100 \mu \mathrm{L}$ of $10 \%(w / v)$ Triton X-114, $80 \mu \mathrm{L}$ of $10 \%(w / v)$ egg yolk phospholipids in the form of sonicated liposomes, 2-oxoglutarate, $200 \mu \mathrm{L}$ of $10 \mathrm{mg} / \mathrm{mL}$ asolectin and $10 \mathrm{mM}$ Pipes, $\mathrm{pH} 7.0$, in a final volume of $700 \mu \mathrm{L}$. After vortexing, the mixture was transferred into the Eppendorf tube $(2 \mathrm{~mL})$ containing $0.4 \mathrm{~g}$ Amberlite Bio-Beads SM- 2 and, after rotating at $32 \mathrm{rpm}$, the proteoliposomes were recovered by gentle aspiration. All the operations were performed at room temperature.

\subsection{Transport Measurements}

The external substrate was removed by passing $650 \mu \mathrm{L}$ of the proteoliposomes through a Sephadex G-75 column $(0.7 \times 15 \mathrm{~cm})$, pre-equilibrated with $50 \mathrm{mM} \mathrm{NaCl} / 10 \mathrm{mM}$ Pipes ( $\mathrm{pH}$ 7.0). The first turbid fraction from the Sephadex G-75 column $(600 \mu \mathrm{L})$ was collected 
and distributed into reaction vessels (100 $\mu \mathrm{L}$ each) for transport measurements by the inhibitor stop method [51]. The transport activity was determined by measuring the flux of labeled 2-oxoglutarate from inside to outside (efflux experiments) or outside to inside (uptake experiments). For efflux experiments, proteoliposomes containing $6 \mathrm{mM}$ internal 2-oxoglutarate were loaded with $0.1 \mathrm{mM}\left[{ }^{14} \mathrm{C}\right]$ 2-oxoglutarate at high specific radioactivity for $30 \mathrm{~min}$ at $25^{\circ} \mathrm{C}$ by carrier-mediated exchange equilibrium. After incubation time, the external radioactivity was removed by passing the proteoliposomes through Sephadex G-75 columns pre-equilibrated with $50 \mathrm{mM} \mathrm{NaCl}$. Transport was started by adding either unlabeled 2-oxoglutarate at the indicated concentrations in a buffer of $50 \mathrm{mM} \mathrm{NaCl}, 10 \mathrm{mM}$ Pipes (pH 7.0) (backward exchange), buffer alone, DMSO solvent or hemin, as indicated in the context of each experiment and stopped at the desired time. In the case of uptake experiments (forward exchange), transport was started by adding from outside the labeled substrate to proteoliposomes containing 2-oxoglutarate and stopped after $2 \mathrm{~min}$ by adding $10 \mu \mathrm{L}$ of $350 \mathrm{mM}$ pyridoxal 5'-phosphate (PLP) as an inhibitor. External radioactivity was removed by a Sephadex G-75 column $(0.6 \times 8 \mathrm{~cm})$ and the proteoliposomes eluted with $1.2 \mathrm{~mL}$ of $50 \mathrm{mM} \mathrm{NaCl}$ were collected in $4 \mathrm{~mL}$ of scintillation mixture. In control samples, the inhibitor was added together with the labeled substrate at time zero and run in duplicate with the assay temperature at $25^{\circ} \mathrm{C}$. The transport activity was calculated by subtracting the control value from the experimental values, and expressed as $\mathrm{mmol} / \mathrm{g}$ protein or as intraliposomal counts per minute $(\mathrm{cpm})$. The values represented are the means \pm SD from three independent experiments.

\subsection{Protein Quantification}

Polyacrylamide gel electrophoresis of precipitated proteins was performed in accordance to the method of Laemmli in the presence of $0.1 \%$ SDS [52]. The stacking gel (5\% $w / v$ of polyacrylamide) and the separation gel $(17.5 \% w / v$ of polyacrylamide) were prepared with an acrylamide/bisacrylamide ratio of 38:1. Staining was performed by the silver nitrate method [53] and protein concentration was determined by the Lowry method modified for the presence of non-ionic detergents [54]. All the samples used for protein determination were dissolved in $1 \%(w / v)$ SDS.

\subsection{Induced-Fit Molecular Docking}

The homology model of the OGC carrier 3D structure herein used was built with Modeller [55] by taking the structure of the bovine AAC1 as a template, whose entry in the Protein Data Bank is 1OKC [56]. WHAT IF web server [57] was employed for assessing the goodness of both structural and energetic properties of the generated 3D comparative model. More details are available from the reference papers [58,59]. The OGC 3D structure was subsequently treated with the Protein Preparation Tool [60] of the Schrodinger suite for further checks on protonation states at physiological $\mathrm{pH}$ and tautomers. Hemin structure was retrieved from the Cambridge Crystallographic Data Centre (CCDC) [61,62]. A zero-order bond was assigned for flagging coordination bonds between $\mathrm{Fe}^{3+}$ cations and nitrogen atoms of the porphyrin ring and between $\mathrm{Fe}^{3+}$ cations and $\mathrm{Cl}^{-}$anions. The 2-oxoglutarate structure was treated with the LigPrep tool [60] in order to generate all possible tautomerization states along with protonation states at physiological $\mathrm{pH}$. Ligand structures were finally minimized by employing prime package [63]. The induced-fit docking protocol [63] was employed by using Glide [64] with an OPLS3e force field [65] in order to inspect the binding mode of the selected ligands together with conformational changes within the receptor, the latter not detectable in the standard docking protocol. Notably, the employed induced-fit docking protocol is coherent with the induced transition fit of transport catalysis, commonly accepted for explaining substrate translocation along mitochondrial carriers [66]. The enclosing box was centered on the center of mass of key residues R288, R190 and R90, representing the crucial residues of the OGC binding catalytic pocket when OGC is open towards the cytosolic side, according to the similarly located shared mitochondrial binding site [36]. Side-chain predictions were 
performed on residues within $6 \AA$ from ligand poses together with Glide SP redocking of each protein-ligand complex structure within $30.0 \mathrm{kcal} / \mathrm{mol}$ of the lowest energy.

\section{Results}

The effect of hemin (Figure 1, panel A), a porphyrin derivative, on the uptake of labeled 2-oxoglutarate or labeled malate mediated by the purified OGC (Figure 1, panel B) was investigated.

A

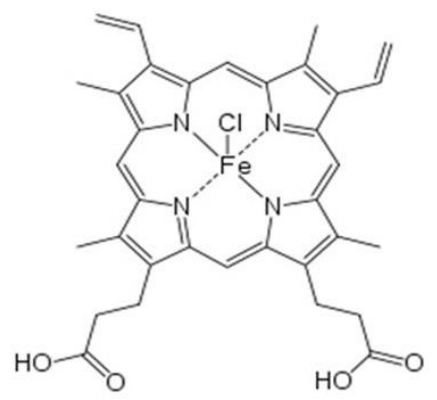

B

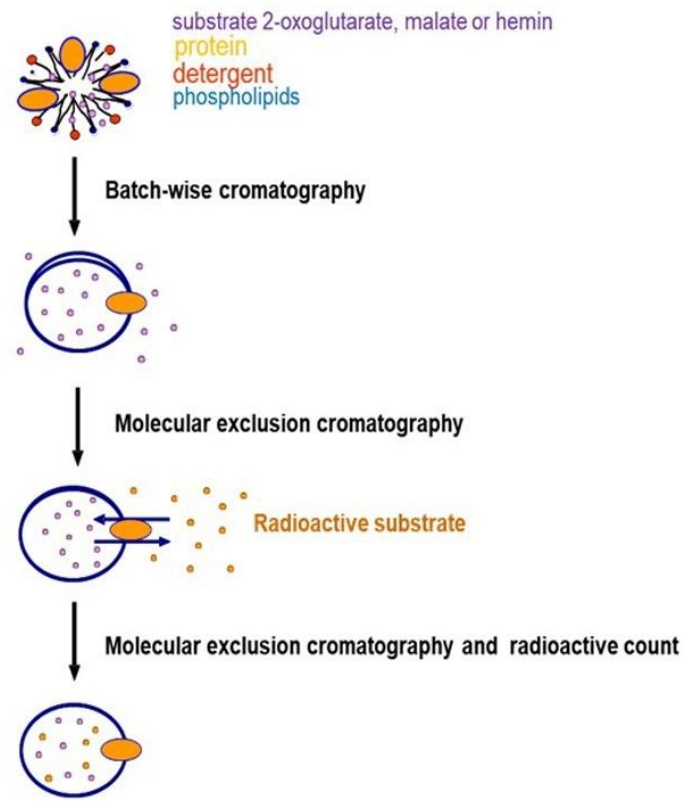

Figure 1. Panel (A), chemical structure of hemin. Panel (B), schematic representation of protein reconstitution and transport system.

Figure 2 shows that hemin exerted about $50 \%$ of inhibition on the $\left[{ }^{14} \mathrm{C}\right]$ 2-oxoglutarate or $\left[{ }^{14} \mathrm{C}\right]$ malate uptake rate at about $2 \mu \mathrm{M}\left(\mathrm{IC}_{50} 1.58 \pm 0.22 \mu \mathrm{M}\right.$ and $\mathrm{IC}_{50} 1.66 \pm 0.14 \mu \mathrm{M}$, respectively) in proteoliposomes loaded with internal $6 \mathrm{mM}$ of 2-oxoglutarate.

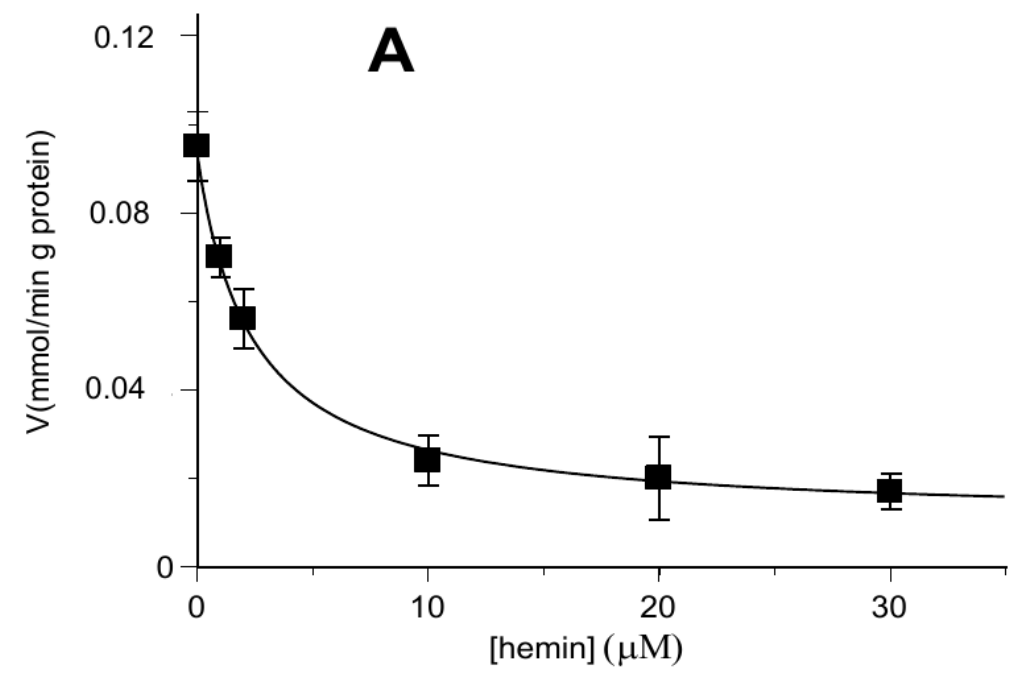

Figure 2. Cont. 


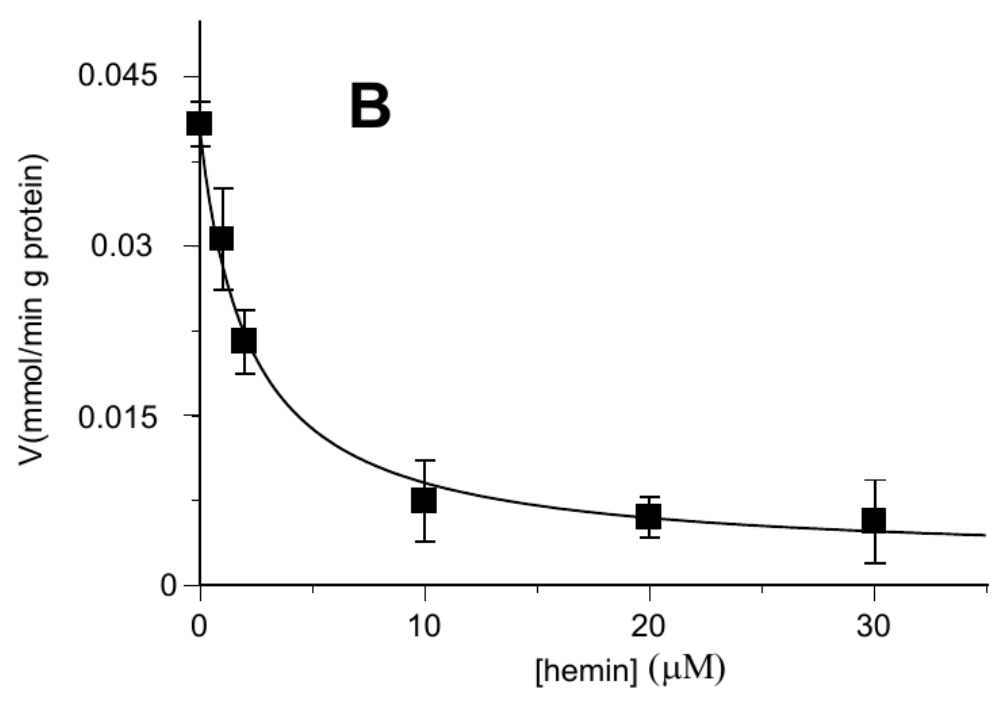

Figure 2. Hemin inhibition of the OGC-mediated uptake of $\left[{ }^{14} \mathrm{C}\right] 2$-oxoglutarate and $\left[{ }^{14} \mathrm{C}\right]$ malate. The transport rate of $\left[{ }^{14} \mathrm{C}\right]$ 2-oxoglutarate in homo-exchange $(\mathrm{A})$ or $\left[{ }^{14} \mathrm{C}\right]$ malate in hetero-exchange (B) was measured in $2 \mathrm{~min}$ in the absence and in the presence of increasing concentrations of hemin $(1-30 \mu \mathrm{M})$. Hemin was added together with $\left[{ }^{14} \mathrm{C}\right] 2$-oxoglutarate or $\left[{ }^{14} \mathrm{C}\right]$ malate at a concentration of $0.05 \mathrm{mM}$ to proteoliposomes containing $6 \mathrm{mM}$ of 2-oxoglutarate. Values are means \pm S.D. from three independent experiments.

When the rate of uptake was measured as a function of the external substrate in the presence of different hemin concentrations, the inhibition was clearly revealed to be a competitive type both for the 2-oxoglutarate and the malate, as reported on double reciprocal plots (Lineweaver-Burk) of Figure 3A,B, respectively.

An obvious consequence of this result has been to verify whether hemin was a substrate of the OGC according to the single binding centre gated pore mechanism which implies that the carrier has a single binding site for its substrates and can rearrange itself between the inside and outside form, in both the free and substrate-bound states $[16,48,49]$.

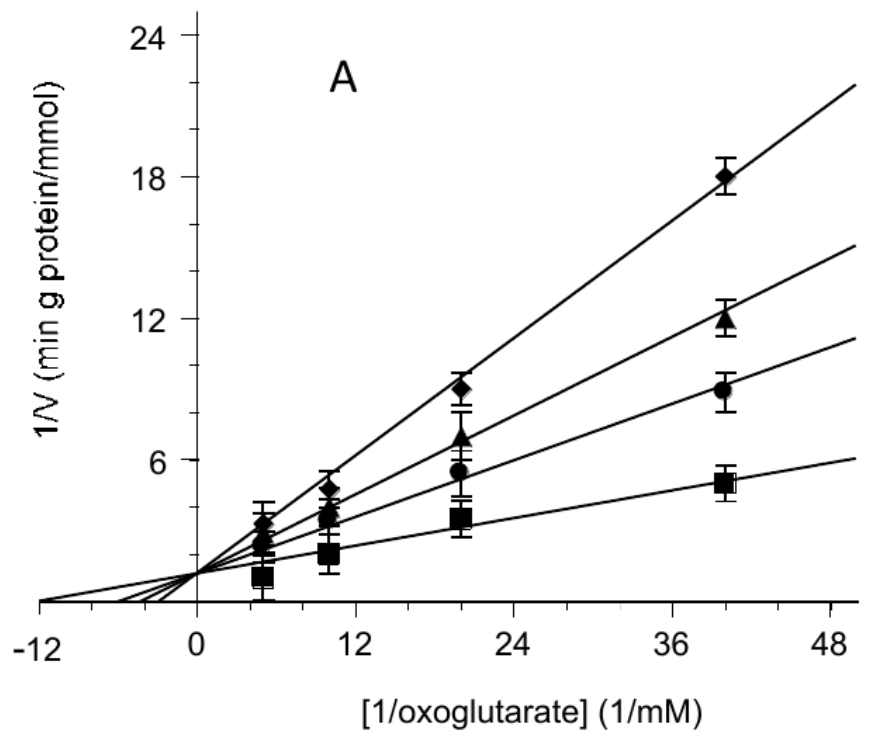

Figure 3. Cont. 




Figure 3. Competitive inhibition of the 2-oxoglutarate or malate transport activity by hemin. Double reciprocal plot showing the dependence of the uptake rate on hemin external concentrations. The transport rate of $\left[{ }^{14} \mathrm{C}\right]$ 2-oxoglutarate $(\mathbf{A})$ or $\left[{ }^{14} \mathrm{C}\right]$ malate $(\mathbf{B})$ in proteoliposomes containing $6 \mathrm{mM}$ of 2-oxoglutarate was measured in $2 \mathrm{~min}$ in the absence $(\mathbf{\square})$ or presence of hemin at $0.5 \mu \mathrm{M}(\bullet), 2 \mu \mathrm{M}$ $(\mathbf{\Delta})$ and $3.5 \mu \mathrm{M}(\boldsymbol{\vee})$. Hemin was added together with $\left[{ }^{14} \mathrm{C}\right]$ 2-oxoglutarate $(\mathbf{A})$ or $\left[{ }^{14} \mathrm{C}\right]$ malate $(\mathbf{B})$ at concentrations of $0.025 \mathrm{mM}, 0.05 \mathrm{mM}, 0.1 \mathrm{mM}$ and $0.2 \mathrm{mM}$. The data are the means $\pm \mathrm{SD}$ from three different experiments.

Then, we performed the uptake of $\left[{ }^{14} \mathrm{C}\right]$ 2-oxoglutarate into proteoliposomes loaded with 2-oxoglutarate or hemin, respectively. The results are described in Figure 4 where the time course of the labeled 2-oxoglutarate uptake was analyzed. The uptake in the presence of hemin inside the proteoliposomes was quite small with respect to the oxoglutarate/oxoglutarate exchange, at the same level of the very poor substrate uptake by proteoliposomes containing only the Pipes buffer. This rules out the possibility for hemin to be transported.

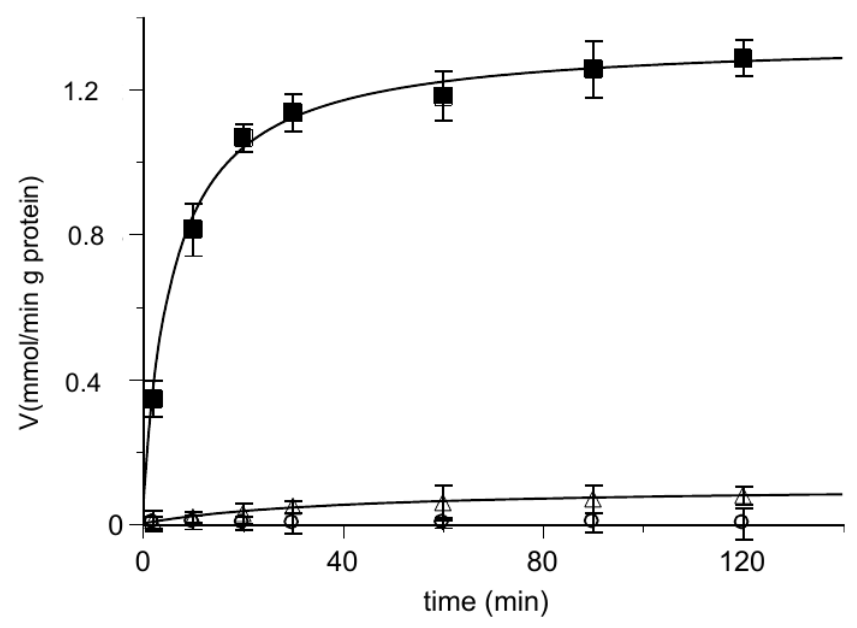

Figure 4. Time course of $\left[{ }^{14} \mathrm{C}\right]$ 2-oxoglutarate uptake in reconstituted proteoliposomes. At zero time, $0.025 \mathrm{mM}\left[{ }^{14} \mathrm{C}\right]$ 2-oxoglutarate is added to reconstituted proteoliposomes containing $6 \mathrm{mM}$ of 2-oxoglutarate $(\mathbf{\square}), 50 \mu \mathrm{M}$ hemin $(\bigcirc)$ or $10 \mathrm{mM}$ Pipes $(\triangle)$. Transport was stopped by adding $10 \mu \mathrm{L}$ of PLP $350 \mathrm{mM}$ at the indicated times and the intraliposomal radioactivity was measured. The data are the means \pm SD from three different experiments. 
Further information has been obtained by evaluating the uptake rate as a function of the hemin concentration, in a range indicated by the data of Figure 2. In the Dixon plots (Figure 5), the reciprocals of uptake rates for each substrate (2-oxoglutarate and malate) were plotted as a function of hemin concentrations. It is evident that in both cases the data could hardly fit to straight lines, as one would expect for a pure competitive inhibition in analogy to classic enzyme kinetics, as hemin concentration increases beyond $10 \mu \mathrm{M}$. Maybe it is due to the targeting of other protein regions not directly involved in substrate binding and/or translocation but likely involved in protein conformational changes (see also the Discussion Section). In addition, higher concentrations of hemin with phospholipids or additional kinetic regulatory effects might alter proteoliposome integrity, accordingly to what has been previously reported [67].
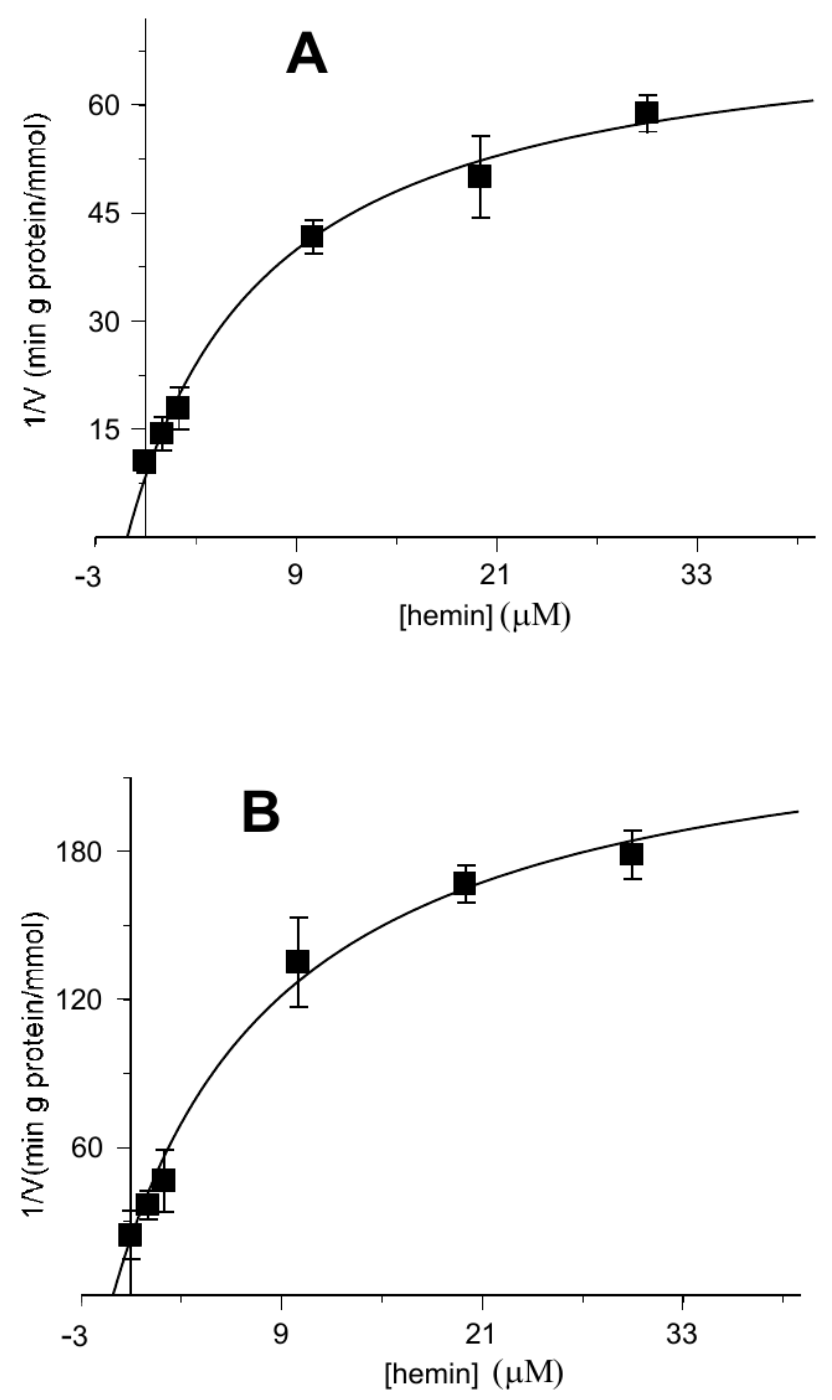

Figure 5. Kinetic analysis of the inhibition data of Figure 2 of the reconstituted oxoglutarate/oxoglutarate and malate/oxoglutarate exchanges by hemin using the Dixon plot. Hemin was added together with $0.05 \mathrm{mM}$ of $\left[{ }^{14} \mathrm{C}\right]$ 2-oxoglutarate $(\mathbf{A})$ or $0.05 \mathrm{mM}\left[{ }^{14} \mathrm{C}\right]$ malate $(\mathbf{B})$ to proteoliposomes containing $6 \mathrm{mM}$ of 2-oxoglutarate in the absence or in the presence of increasing hemin concentrations (1-30 $\mu \mathrm{M})$.

In order to verify if hemin inside the proteoliposomes behaved in the same way as outside them, experiments were performed with proteoliposomes loaded with hemin and substrate, then labeled 2-oxoglutarate uptake was analyzed. Once established that hemin alone had no effect (Figure 4), the experiment described in Figure 6 shows that, also in this 
case, hemin inhibited the substrate influx, again in the order of micromolar concentrations. The determined $\mathrm{IC}_{50}$ value of $1.99 \pm 0.16 \mu \mathrm{M}$ obtained by preloading proteoliposomes with hemin (Figure 6) is comparable to those obtained from the experiments in which hemin was added from the outside (Figure 2).

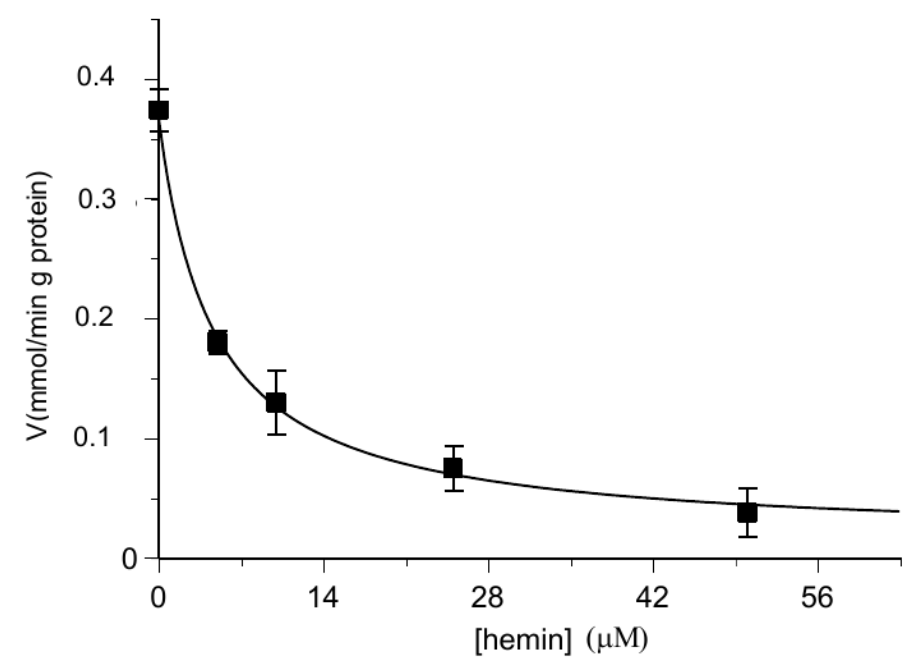

Figure 6. Inhibition of the transport activity of the $\left[{ }^{14} \mathrm{C}\right] 2$-oxoglutarate in the OGC carrier by hemin preloaded within proteoliposomes. The transport rate of $\left[{ }^{14} \mathrm{C}\right] 2$-oxoglutarate in proteoliposomes containing $6 \mathrm{mM}$ of 2-oxoglutarate and increasing concentrations of hemin $(0-50 \mu \mathrm{M})$ was measured in $2 \mathrm{~min}$. Additionally, $\left[{ }^{14} \mathrm{C}\right] 2$-oxoglutarate was added at a concentration of $0.025 \mathrm{mM}$. The values are the means $\pm \mathrm{SD}$ from three independent experiments.

Furthermore, loading proteoliposomes with labeled 2-oxoglutarate makes it possible to analyze the substrate efflux step occurring during the exchange process, both in the presence and the absence of hemin (Figure 7). Additionally, in this case the possibility for hemin to be transported is excluded.

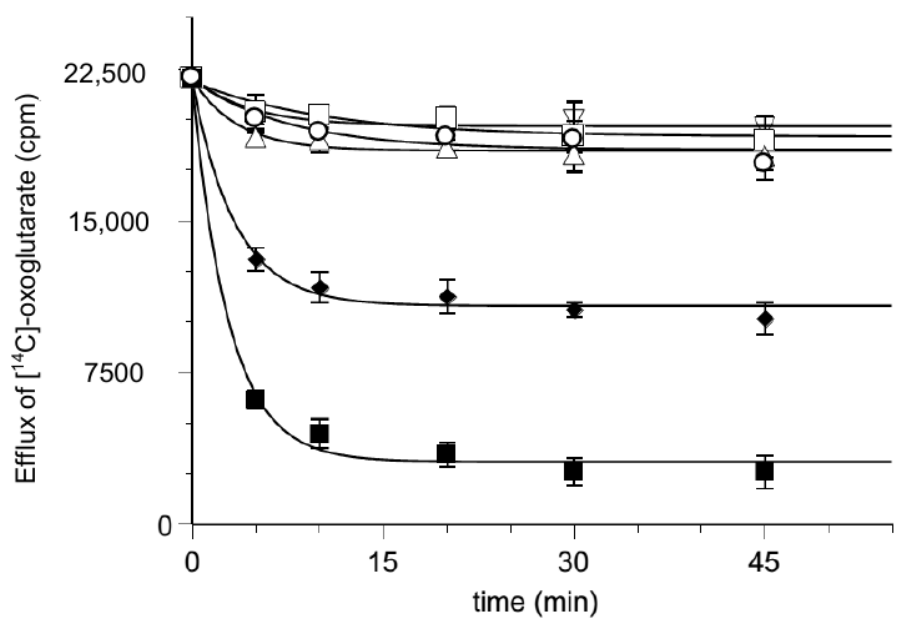

Figure 7. Effect of hemin on the time course of $\left[{ }^{14} \mathrm{C}\right]$ 2-oxoglutarate efflux from proteoliposomes. Efflux of $\left[{ }^{14} \mathrm{C}\right]$ 2-oxoglutarate from pre-labeled proteoliposomes with radioactive substrates was measured as described in Materials and Methods in the presence of external $50 \mathrm{mM} \mathrm{NaCl}$ and $10 \mathrm{mM}$ Pipes pH 7 buffer $(\nabla)$, DMSO solvent $(\triangle), 0.025 \mathrm{mM}$ 2-oxoglutarate $(\bullet), 0.25 \mathrm{mM}$ 2-oxoglutarate $(\boldsymbol{\square})$, $0.010 \mathrm{mM}$ hemin $(\square)$ and $0.010 \mathrm{mM}$ hemin with $0.025 \mathrm{mM}$ 2-oxoglutarate $(\bigcirc)$ added at time 0 . The data are the means \pm SD from three different experiments. 


\section{Molecular Docking Analyses}

For investigating the putative interaction of hemin with the OGC binding region proposed for 2-oxoglutarate, molecular docking analyses were performed to shed light on the interactions of hemin and 2-oxoglutarate towards OGC, whose 3D structure was built by homology modeling based on the bovine AAC1 template retrieved from the Protein Data Bank with code 1OKC. As shown in Figure 8, a network of electrostatic and hydrogen bond interactions is shared between hemin and 2-oxoglutarate. In particular, the carboxylic groups of 2-oxoglutarate can interact with R288, R90 and R190 as well as with the side-chain of Y285. On the other hand, the carboxyl groups on the hemin arms can play the same ionic interactions experienced from 2-oxoglutarate with protonated nitrogen atoms of R90, R190 and R288 residues. Notably, the three residues represent the main three contact points of the mitochondrial carrier similarly located on the common substrate binding site $[37,68]$. For the sake of completeness, docking score values returned from in silico analyses were equal to $-10.182 \mathrm{kcal} / \mathrm{mol}$ and $-5.519 \mathrm{kcal} / \mathrm{mol}$ for hemin and 2-oxoglutarate, respectively, making these results coherent with the experimental data.
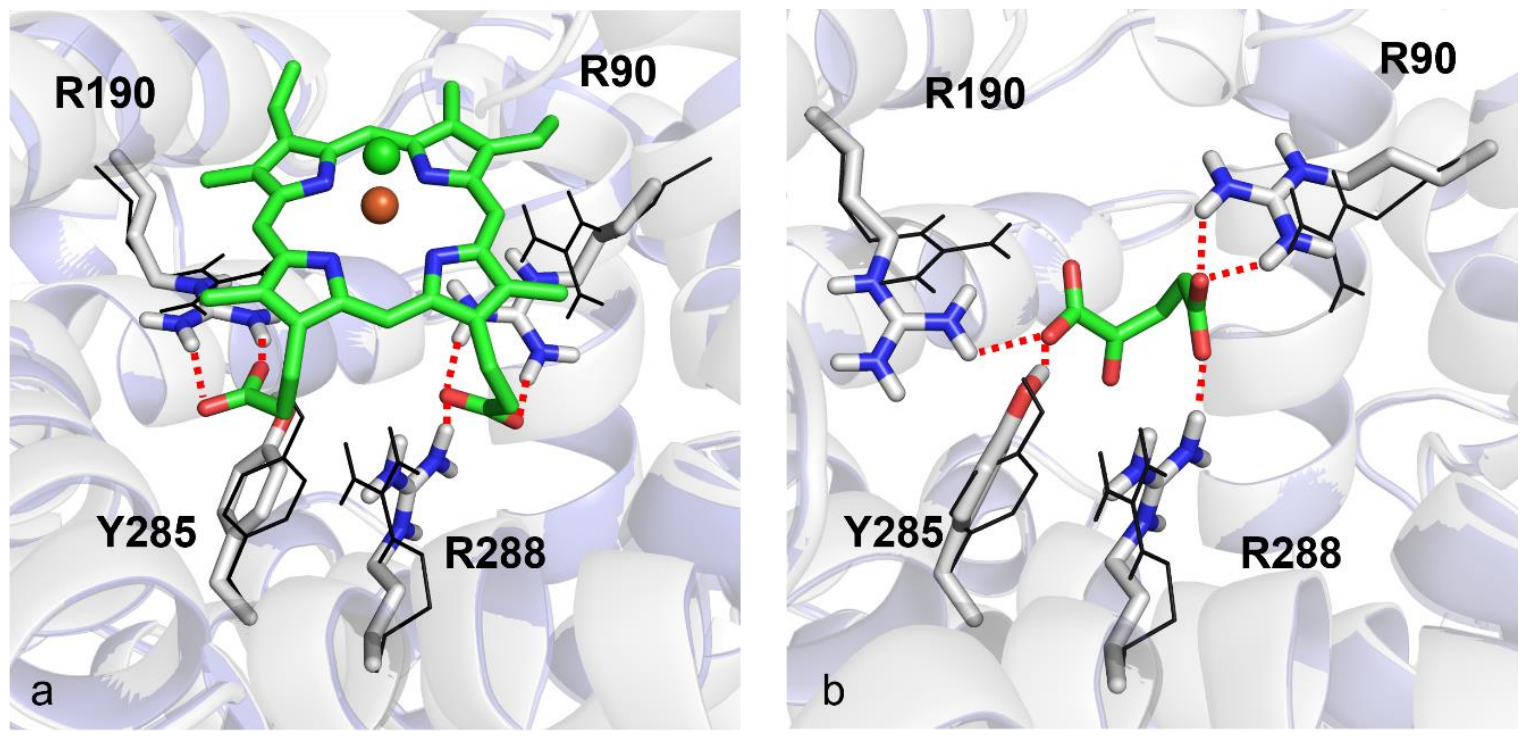

Figure 8. Induced-fit molecular docking. Panels (a) and (b) show the top-scored poses returned from docking analyses for hemin and 2-oxoglutarate within the OGC homology model built by using the bovine crystallized AAC1 as a template (PDB_ID: 1OKC). Red dotted lines indicate hydrogen bonds. $\mathrm{Fe}^{3+}$ and $\mathrm{Cl}^{-}$ions are depicted as orange and green spheres, respectively. Black wireframes show the initial positions of key residue side-chains before induced-fit docking simulations.

\section{Discussion}

The general equation of the rate of substrate transport reported in refs. [48,49] describes the rate of influx of a substrate into the internal phase of proteoliposomes (or any space delimited by a membrane), when mediated by a specific carrier-protein according to the single binding centre gated pore mechanism [16,48,49]. In analogy with enzyme kinetics, we use the reasonable postulate that the interactions between the carrier and its substrates represent the fast steps of the process. The rearrangement steps of the carrier inside the membrane, leading to the exposition of the binding site (either with a bound substrate or free) towards the intermembrane space (carrier in the cytosolic c-conformation, refs. [36,43-46,56]) or towards the matrix space (carrier in the matrix mconformation) [69-71], are relatively slow and thus rate determining. Consequently, in any transport rate equation, the rate " $\mathrm{v}$ " will depend on the concentration of the substrates and inhibitors, as well as on their dissociation constants and on the kinetic constants of the rearrangement steps. In particular, we use the following notations: 
$\mathrm{A}=$ (2-oxoglutarate) $\mathrm{B}=$ (L-malate) $\mathrm{E}=$ (hemin),

$\mathrm{K}_{\mathrm{A}}=$ Carrier-2-oxoglutarate dissociation constant,

$\mathrm{K}_{\mathrm{B}}=$ Carrier-L-malate dissociation constant,

$\mathrm{K}_{\mathrm{E}}=$ Carrier-hemin dissociation constant,

$\mathrm{k}_{2}$ and $\mathrm{k}_{-2}=$ kinetic constants of outside-inside and inside-outside rearrangement of the carrier-oxoglutarate complex,

$\mathrm{k}_{3}$ and $\mathrm{k}_{-3}=$ kinetic constants of outside-inside and inside-outside rearrangement of the free carrier,

In the simple case of homo-exchange, with one substrate present in both the external $A_{e}$ and the internal phase $A_{i}$, the equation is:

$$
\begin{gathered}
\mathrm{v}=\mathrm{V}_{\mathrm{M}} \cdot \frac{\mathrm{A}_{\mathrm{e}}}{\mathrm{A}_{\mathrm{e}}+\mathrm{K}_{\mathrm{M}}} \\
\text { where } \mathrm{V}_{\mathrm{M}}=\mathrm{k}_{2} \cdot \mathrm{C}_{\mathrm{T}} \cdot \frac{\mathrm{k}_{-2} \mathrm{~A}_{\mathrm{i}}+\mathrm{k}_{-3} \mathrm{~K}_{\mathrm{Ai}}}{\left(\mathrm{k}_{-2}+\mathrm{k}_{2}\right) \mathrm{A}_{\mathrm{i}}+\left(\mathrm{k}_{-3}+\mathrm{k}_{2}\right) \mathrm{K}_{\mathrm{Ai}}} \\
\text { and } \mathrm{K}_{\mathrm{M}}=\frac{\left(\mathrm{k}_{-2}+\mathrm{k}_{3}\right) \mathrm{A}_{\mathrm{i}}+\left(\mathrm{k}_{-3}+\mathrm{k}_{3}\right) \mathrm{K}_{\mathrm{Ai}}}{\left(\mathrm{k}_{-2}+\mathrm{k}_{2}\right) \mathrm{A}_{\mathrm{i}}+\left(\mathrm{k}_{-3}+\mathrm{k}_{2}\right) \mathrm{K}_{\mathrm{Ai}}} \mathrm{K}_{\mathrm{Ae}}
\end{gathered}
$$

when the external substrate is malate, the terms $A_{e}, K_{A e}$ and $k_{2}$ are substituted by $B_{e}$, $\mathrm{K}_{\mathrm{Be}}$ and $\mathrm{k}_{4}$, whereas when malate is the internal substrate, the terms $\mathrm{A}_{\mathrm{i}}, \mathrm{K}_{\mathrm{Ai}}$ and $\mathrm{k}_{-2}$ are substituted by $\mathrm{B}_{\mathrm{i}}, \mathrm{K}_{\mathrm{Bi}}$ and $\mathrm{k}_{-4}$.

The presence of a third molecule (hemin) outside the proteoliposomes, able to interact with the carrier, requires a new elaboration of the rate equation, taking this presence into account.

In fact, hemin is revealed to be a very effective inhibitor of the oxoglutarate/oxoglutarate and malate/oxoglutarate exchange promoted by the OGC carrier purified from rat brain mitochondria and reconstituted into proteoliposomes.

According to our transport assays, hemin competitively inhibits the transport of both substrates, 2-oxoglutarate and malate (Figure 3A,B), and this could be easily explained by an interaction between hemin and the OGC while competing with the substrate. For analysing transport assays in the presence of hemin, the rate equation would contain two additional terms: the hemin concentration and the dissociation constant of the hemincarrier complex. The modified equation again has the Michaelian saturation form as in Equation (1), with an unmodified $V_{M}$ and a $K_{M}$ that is a linear function of the hemin concentration; as for the competitive inhibition in enzyme kinetics:

$$
\mathrm{K}_{\mathrm{M}}=\frac{\left(\mathrm{k}_{-2} \mathrm{~A}_{\mathrm{i}}+\mathrm{k}_{-3} \mathrm{~K}_{\mathrm{Ai}}\right) \mathrm{E}+\left(\left(\mathrm{k}_{-2}+\mathrm{k}_{3}\right) \mathrm{A}_{\mathrm{i}}+\left(\mathrm{k}_{-3}+\mathrm{k}_{3}\right) \mathrm{K}_{\mathrm{Ai}}\right) \mathrm{K}_{\mathrm{E}}}{\left(\left(\mathrm{k}_{-2}+\mathrm{k}_{2}\right) \mathrm{A}_{\mathrm{i}}+\left(\mathrm{k}_{-3}+\mathrm{k}_{2}\right) \mathrm{K}_{\mathrm{Ai}}\right) \mathrm{K}_{\mathrm{E}}}
$$

In addition, the equations for the rate " $\mathrm{v}$ " and its reciprocal " $1 / \mathrm{v}$ " as functions of the inhibitor concentration can be derived:

$$
\begin{gathered}
\mathrm{v}=\frac{\mathrm{V}_{0}}{1+\frac{1}{\mathrm{~K}_{0.5}} \mathrm{E}} \\
\text { and } \frac{1}{\mathrm{v}}=\frac{1}{\mathrm{~V}_{0}}+\frac{1}{\mathrm{~V}} \cdot \frac{\mathrm{K}_{\mathrm{Ae}}}{\mathrm{K}_{\mathrm{E}}} \cdot \mathrm{E}
\end{gathered}
$$

with

$$
\mathrm{V}_{0}=\mathrm{V} \cdot \frac{\left(\mathrm{k}_{-2} \mathrm{~A}_{\mathrm{i}}+\mathrm{k}_{-3} \mathrm{~K}_{\mathrm{Ai}}\right) \mathrm{A}_{e}}{\left(\left(\mathrm{k}_{-2}+\mathrm{k}_{2}\right) \mathrm{A}_{\mathrm{i}}+\left(\mathrm{k}_{-3}+\mathrm{k}_{2}\right) \mathrm{K}_{\mathrm{Ai}}\right) \mathrm{A}_{\mathrm{e}}+\left(\left(\mathrm{k}_{-2}+\mathrm{k}_{3}\right) \mathrm{A}_{\mathrm{i}}+\left(\mathrm{k}_{-3}+\mathrm{k}_{3}\right) \mathrm{K}_{\mathrm{Ai}}\right) \mathrm{K}_{\mathrm{Ae}}}
$$


And

$$
\mathrm{K}_{0.5}=\frac{\left(\left(\mathrm{k}_{-2}+\mathrm{k}_{2}\right) \mathrm{A}_{\mathrm{i}}+\left(\mathrm{k}_{-3}+\mathrm{k}_{2}\right) \mathrm{K}_{\mathrm{Ai}}\right) \mathrm{A}_{\mathrm{e}}+\left(\left(\mathrm{k}_{-2}+\mathrm{k}_{3}\right) \mathrm{A}_{\mathrm{i}}+\left(\mathrm{k}_{-3}+\mathrm{k}_{3}\right) \mathrm{K}_{\mathrm{Ai}}\right) \mathrm{K}_{\mathrm{Ae}}}{\left(\mathrm{k}_{-2} \mathrm{~A}_{\mathrm{i}}+\mathrm{k}_{-3} \mathrm{~K}_{\mathrm{Ai}}\right) \mathrm{K}_{\mathrm{Ae}}} \mathrm{K}_{\mathrm{Ee}}
$$

where $\mathrm{V}_{0}$ and $\mathrm{K}_{0.5}$ depend on $\mathrm{A}_{\mathrm{e}}$ with $\mathrm{A}_{\mathrm{i}}$ constant.

The rate " $\mathrm{v}$ " is a decreasing asymptotic function of " $\mathrm{E}$ ", with the abscissa as an asymptote at any substrate concentration, while " $1 / \mathrm{v}$ " is a linear function of the inhibitor (Dixon plot). Our experimental data of Figure 2 and 6 fit to these decrement trends. In Figure 5 the linear trend is evident below the point at $10 \mu \mathrm{M}$ of hemin, which can bind OGC by inhibiting 2-oxoglutarate and malate translocation. At higher concentrations the straight line curves, probably due to damage of proteoliposomes as supported by previous observations, showing that high concentrations of hemin and porphyrin-like derivatives destabilize biological membranes and liposomes [67].

Finally, for supporting the hypothesis formulated about the role played by hemin as an OGC inhibitor, molecular docking analyses showed that the negatively charged carboxylic groups of hemin interact with the three arginine residues, forming the three contact points of the OGC substrate binding region with an orientation very similar to the orientation observed for the carboxylic functional groups of 2-oxoglutarate, when the carrier is in c-conformation.

Moreover, hydrogen bonds with R288, R190 and R90 stabilize the structure of hemin within the OGC binding pocket, forming a protein-ligand complex even stronger than the OGC-2-oxoglutarate protein-ligand complex (OGC-hemin docking score equal to $-10.182 \mathrm{kcal} / \mathrm{mol}$ versus OGC-2-oxoglutarate docking score equal to $-5.519 \mathrm{kcal} / \mathrm{mol}$ ).

Although hemin can be detected in various body fluids such as saliva and urine under various pathological states, it exists in cells at a very low concentration ( $\mu \mathrm{M}$ range). Some previous papers state that about $80 \%$ of total hemin in plasma binds initially to LDL and $\mathrm{HDL}$, while in mitochondria hemin might be present at concentration $<10 \mu \mathrm{M}[72,73]$. It is known that OGC participates in the malate/aspartate shuttle used by mammalia cells as a pathway for transferring reducing equivalents from mitochondria to the cytosol [28]. The impairment of the malate/aspartate shuttle may trigger the impairment of mitochondrial respiration and thus inhibitory interactions between hemin-like molecules and OGC may participate in regulating mitochondrial apoptosis. In addition, since hemin also appears to be able to trigger or prevent mitochondrial dysfunction, refs. $[17,18]$ and free hemin in mammals can exert a neuroprotective effect [21], conversely it can induce mitochondrial dysfunction in endothelial cells and in neuroblastoma SH-SY5Y cells [17,74]. In light of our findings showing that OGC can interact with hemin on mitochondrial function $[17,18]$, it might be speculated that OGC can bind hemin and/or porphyrin like ligands (i.e., released by heme-dependent protein complexes, partially damaged from oxidative stress, ageing or disease conditions). It is resulting in OGC inhibition and in the impairment of the malate/aspartate shuttle for favoring mitophagy/autophagy, in presence of a low excess of porphyrin-like molecules [17-21]. If the oxidative damage is more serious, in presence of an excess of hemin and other porphyrin-like molecules, the inhibition of malate/aspartate shuttle is more severe, favoring the alteration of lipid peroxidation pathways and mitochondrial apoptosis. Notably, mitochondrial apoptosis might also be favored by membrane leakage induced by the higher concentration of porphyrin-like molecules [19].

Author Contributions: Conceptualization, D.V.M., A.S. and A.D.P.; methodology, D.V.M., A.D.P., V.S. and A.S.; computational analysis, N.G., O.N. and C.L.P.; data curation, D.V.M., A.D.P., A.S., N.G., O.N. and C.L.P.; supervision D.V.M., A.D.P., A.S., N.G., O.N. and C.L.P. All authors have read and agreed to the published version of the manuscript.

Funding: This research received no external funding.

Institutional Review Board Statement: Not applicable. 
Informed Consent Statement: Not applicable.

Data Availability Statement: Not applicable.

Acknowledgments: This manuscript is in memory of Professor Prezioso Girolamo, who inspired this work.

Conflicts of Interest: The authors declare no conflict of interest.

\section{References}

1. Kim, H.J.; Khalimonchuk, O.; Smith, P.M.D.; Winge, R. Structure, function, and assembly of heme centers in mitochondrial respiratory complexes. Biochim. Biophys. Acta 2012, 1823, 1604-1616. [CrossRef]

2. Kalainayakan, S.P.; FitzGerald, K.E.; Konduri, P.C.; Vidal, C.; Zhang, L. Essential roles of mitochondrial and heme function in lung cancer bioenergetics and tumorigenesis. Cell Biosci. 2018, 8, 56. [CrossRef] [PubMed]

3. Cox, T.C.; Bottomley, S.S.; Wiley, J.S.; Bawden, M.J.; Matthews, C.S.; May, B.K. X-linked pyridoxine-responsive sideroblastic anemia due to a Thr-388-to-Ser substitution in erythroid 5-aminolevulinate synthase. N. Engl. J. Med. 1994, 330, 675-679. [CrossRef]

4. Chiabrando, D.; Mercurio, S.; Tolosano, E. Heme and erythropoieis: More than a structural role. Haematologica 2014, 99, 973-983. [CrossRef]

5. Ajioka, R.S.; Phillips, J.D.; Kushner, J.P. Biosynthesis of heme in mammals. Biochim. Biophys. Acta 2006, 1763, 723-736. [CrossRef]

6. Elder, G.H.; Evans, J.O. Evidence that the coproporphyrinogen oxidase activity of rat liver is situated in the intermembrane space of mitochondria. Biochem. J. 1978, 172, 345. [CrossRef] [PubMed]

7. Grandchamp, B.; Phung, N.; Nordmann, Y. The mitochondrial localization of coproporphyrinogen III oxidase. Biochem. J. 1978, 176, 97. [CrossRef]

8. Poulson, R. The enzymic conversion of protoporphyrinogen IX to protoporphyrin IX in mammalian mitochondria. J. Biol. Chem. 1976, 251, 3730. [CrossRef]

9. Jones, M.S.; Jones, O.T.G. The structural organization of haem synthesis in rat liver mitochondria. Biochem. J. 1969, $113,507$. [CrossRef]

10. Rebeiz, N.; Arkins, S.; Kelley, K.W.; Rebeiz, C.A. Enhancement of coproporphyrinogen III transport into isolated transformed leukocyte mitochondria by ATP. Arch. Biochem. Biophys. 1996, 333, 475-481. [CrossRef] [PubMed]

11. Koller, M.E. Studies on the uptake of porphyrin by isolated rat liver mitochondria with particular emphasis on the effect of hemin. FEBS Lett. 1979, 100, 47-51. [CrossRef]

12. Koller, M.E.; Romslo, I. Uptake of protoporphyrin IX by isolated rat liver mitochondria. Biochem. J. 1980, 188, 329-335. [CrossRef]

13. Lunetti, P.; Damiano, F.; De Benedetto, G.; Siculella, L.; Pennetta, A.; Muto, L.; Paradies, E.; Marobbio, C.M.T.; Dolce, V.; Capobianco, L. Characterization of Human and Yeast Mitochondrial Glycine Carriers with Implications for Heme Biosynthesis and Anemia. J. Biol. Chem. 2016, 291, 19746-19759. [CrossRef] [PubMed]

14. Azuma, M.; Kabe, Y.; Kuramori, C.; Kondo, M.; Yamaguchi, Y.; Handa, H. Adenine Nucleotide Translocator Transports Haem Precursors into Mitochondria. PLoS ONE 2008, 3, e3070. [CrossRef]

15. Palmieri, F. The mitochondrial transporter family SLC25: Identification, properties, and physiopathology. Mol. Aspects Med. 2013, 34, 465-484. [CrossRef]

16. Klingenberg, M. Molecular aspects of the adenine nucleotide carrier from mitochondria. Arch. Biochem. Biophys. 1989, $270,1-14$. [CrossRef]

17. Higdon, A.N.; Benavides, G.A.; Chacko, B.K.; Ouyang, X.; Johnson, M.S.; Landar, A.; Zhang, J.; Darley-Usmar, V.M. Hemin causes mitochondrial dysfunction in endothelial cells through promoting lipid peroxidation: The protective role of autophagy. Am. J. Physiol. Heart Circ. Physiol. 2012, 302, H1394-H1409. [CrossRef] [PubMed]

18. Supinski, G.S.; Callahan, L.A. Hemin prevents cardiac and diaphragm mitochondrial dysfunction in sepsis. Free. Radic. Biol. Med. 2006, 40, 127. [CrossRef] [PubMed]

19. Yang, F.; Shan, Y.; Tang, Z.; Wu, X.; Bi, C.; Zhang, Y.; Gao, Y.; Liu, H. The Neuroprotective Effect of Hemin and the Related Mechanism in Sevoflurane Exposed Neonatal Rats. Front. Neurosci. 2019, 28, 537. [CrossRef]

20. Goldstein, L.; Teng, Z.P.; Zeserson, E.; Patel, M.; Regan, R.F. Hemin induces an iron-dependent, oxidative injury to human neuron-like cells. J. Neurosci. Res. 2003, 73, 113-121. [CrossRef]

21. Zhu, Y.; Sun, Y.; Jin, K.; Greenberg, D.A. Hemin induces neuroglobin expression in neural cells. Blood 2002, 100, 2494-2498. [CrossRef]

22. Ades, I.Z.; Harpe, K.G.; Stevens, T.M. Biogenesis of Mitochondrial proteins regulation of maturation of delta-aminolevulinate synthase by hemin. Biochem. Biophys. Res. Comm. 1983, 110, 42-44. [CrossRef]

23. Yoo, H.J.; Lee, S.H. Heme effects of hemin on growth of peridontopathogens. J. Dent. Rehabil. Appl. Sci. 2021, 37, 31-38. [CrossRef]

24. Bonkovsky, H.L.; Healey, J.F.; Lourie, A.N.; Gerron, G.G. Intravenous heme albumin in acute intermittent porphyria: Evidence for repletion of hepatic hemoproteins and regulatory heme pools. Am. J. Gastroenterol. 1991, 86, 1050-1056. [PubMed]

25. Shoji, M.; Shibata, Y.; Shiroza, T.; Yukitake, H.; Peng, B.; Chen, Y.Y.; Sato, K.; Naito, M.; Abiko, Y.; Reynolds, E.C.; et al. Characterization of hemin-binding protein 35 (HBP35) in Porphyromonas gingivalis: Its cellular distribution, thioredoxin activity and role in heme utilization. BMC Microbiol. 2010, 10, 152. [CrossRef] 
26. Roden, J.A.; Wells, D.H.; Chomel, B.B.; Kasten, R.W.; Koehler, J.E. Hemin binding protein C is found in outer membrane vesicles and protects Bartonella henselae against toxic concentrations of hemin. Infect. Immun. 2012, 80, 929-942. [CrossRef]

27. Kabe, Y.; Ohmori, M.; Shinouchi, K.; Tsuboi, Y.; Hirao, S.; Azuma, M.; Watanabe, H.; Okura, I.; Handa, H. Porphyrin accumulation in mitochondria is mediated by 2-oxoglutarate carrier. J. Biol. Chem. 2006, 281, 31729-31735. [CrossRef]

28. Amoedo, N.D.; Punzi, G.; Obre, E.; Lacombe, D.; De Grassi, A.; Pierri, C.L.; Rossignol, R. AGC1/2 the mitochondrial aspartateglutamate carriers. Bioch. Bioph. Acta 2016, 1863, 2394-2412. [CrossRef] [PubMed]

29. Runswick, M.J.; Walker, J.E.; Bisaccia, F.; Iacobazzi, V.; Palmieri, F. Sequence of the bovine 2-oxoglutarate/malate carrier protein: Structural relationship to other mitochondrial transport proteins. Biochemistry 1990, 29, 11033-11040. [CrossRef]

30. Indiveri, C.; Krämer, R.; Palmieri, F. Reconstitution of the malate/aspartate shuttle from mitochondria. J. Biol. Chem. 1987, 262, 15979-15983. [CrossRef]

31. Indiveri, C.; Dierks, T.; Krämer, R.; Palmieri, F. Reaction mechanism of the reconstituted oxoglutarate carrier from bovine heart mitochondria. Eur. J. Biochem. 1991, 198, 339-347. [CrossRef]

32. Indiveri, C.; Palmieri, F.; Bisaccia, F.; Kramer, R. Kinetics of the reconstituted 2-oxoglutarate carrier from bovine heart mitochondria. Biochim. Biophys. Acta 1987, 890, 310-318. [CrossRef]

33. Palmieri, F. The mitochondrial transporter family (SLC25): Physiological and pathological implications. Pflugers Arch. 2004, 447, 689-709. [CrossRef]

34. Palmieri, F.; Pierri, C.L. Mitochondrial metabolite transport. Essays Biochem. 2010, 47, 37-52. [CrossRef] [PubMed]

35. Palmieri, F.; Pierri, C.L. Structure and function of mitochondrial carriers-Role of the transmembranehelix P and G residues in the gating and transport mechanism. FEBS Lett. 2010, 584, 1931-1939. [CrossRef] [PubMed]

36. Pierri, C.L.; Palmieri, F.; De Grassi, A. Single-nucleotide evolution quantifies the importance of each site along the structure of mitochondrial carriers. Cell. Mol. Life Sci. 2014, 71, 349-364. [CrossRef]

37. Palmieri, F.; Pierri, C.L.; De Grassi, A.; Nunes-Nesi, A.; Fernie, R.A. The plant genome: An evolutionary view on structure and function. Evolution, structure and function of mitochondrial carriers: A review with new insights. Plant J. 2011, 66, 161-181. [CrossRef]

38. Todisco, S.; Di Noia, M.A.; Onofrio, A.; Parisi, G.; Punzi, G.; Redavid, G.; De Grassi, A.; Pierri, C.L. Identification of new highly selective inhibitors of the human ADP/ATP carriers by molecular docking and in vitro transport assays. Biochem. Pharmacol. 2016, 15, 112-132. [CrossRef] [PubMed]

39. Punzi, G.; Porcelli, V.; Ruggiu, M.; Hossain, M.F.; Menga, A.; Scarcia, P.; Castegna, A.; Gorgoglione, R.; Pierri, C.L.; Laera, L.; et al. SLC25A10 biallelic mutations in intractable epileptic encephalopathy with complex I deficiency. Hum. Mol. Genet. 2018, 1, 499-504. [CrossRef]

40. Vozza, A.; De Leonardis, F.; Paradies, E.; De Grassi, A.; Pierri, C.L.; Parisi, G.; Marobbio, C.M.T.; Lasorsa, F.M.; Muto, L.; Capobianco, L.; et al. Biochemical characterization of a new mitochondrial transporter of dephospho-coenzyme A in Drosophila melanogaster. Biochim. Biophys. Acta Bioenerg. 2017, 1858, 137-146. [CrossRef]

41. Regalado, A.; Pierri, C.L.; Bitetto, M.; Laera, V.L.; Pimentel, C.; Francisco, R.; Passarinho, J.; Chaves, M.M.; Agrimi, G. Characterization of mitochondrial dicarboxylate/tricarboxylate transporters from grape berries. Planta 2013, 237, 693-703. [CrossRef]

42. Lunetti, P.; Cappello, A.R.; Marsano, R.M.; Pierri, C.L.; Carrisi, C.; Martello, E.; Caggese, C.; Dolce, V.; Capobianco, L. Mitochondrial glutamate carriers from Drosophila melanogaster: Biochemical, evolutionary and modeling studies. Biochim. Biophys. Acta 2013, 1827, 1245-1255. [CrossRef]

43. Cappello, A.R.; Curcio, R.; Miniero, D.V.; Stipani, I.; Robinson, A.J.; Kunji, E.R.S.; Palmieri, F. Functional and structural role of amino acid residues in the even-numbered transmembrane $\alpha$-helices of the bovine mitochondrial oxoglutarate carrier. J. Mol. Biol. 2006, 363, 51-62. [CrossRef]

44. Cappello, A.R.; Miniero, D.V.; Curcio, R.; Ludovico, A.; Daddabbo, L.; Stipani, I.; Robinson, A.J.; Kunji, E.R.S.; Palmieri, F. Functional and structural role of amino acid residues in the odd-numbered transmembrane $\alpha$-helices of the bovine mitochondrial oxoglutarate carrier. J. Mol. Biol. 2007, 369, 400-412. [CrossRef] [PubMed]

45. Miniero, D.V.; Cappello, A.R.; Curcio, R.; Ludovico, A.; Daddabbo, L.; Stipani, I.; Robinson, A.J.; Kunji, E.R.S.; Palmieri, F. Functional and structural role of amino acid residues in the matrix $\alpha$-helices, termini and cytosolic loops of the bovine mitochondrial oxoglutarate carrier. Bioch. Bioph. Acta Bioenerg. 2011, 1807, 302-310. [CrossRef]

46. Bisaccia, F.; Indiveri, C.; Palmieri, F. Purification of reconstitutively active alpha-oxoglutarate carrier from pig heart mitochondria. Biochim. Biophys. Acta 1985, 810, 362-369. [CrossRef]

47. Natuzzi, D.; Daddabbo, L.; Stipani, V.; Cappello, A.R.; Miniero, D.V.; Capobianco, L.; Stipani, I. Inactivation of the reconstituted oxoglutarate carrier from bovine heart mitochondria by pyridoxal 5'-phosphate. J. Bioenerg. Biomembr. 1999, 31, 535-541. [CrossRef] [PubMed]

48. De Palma, A.; Prezioso, G.; Spagnoletta, A.; Genchi, G.; Scalera, V. The oxoglutarate/malate carrier of rat brain mitochondria operates by a uniport exchange mechanism. J. Bioenerg. Biomembr. 2010, 42, 371-379. [CrossRef] [PubMed]

49. De Palma, A.; Prezioso, G.; Scalera, V. Kinetic Evidence for the Uniport Mechanism Hypothesis in the Mitochondrial Tricarboxylate Transport System. J. Bioenerg. Biomembr. 2005, 37, 279-287. [CrossRef]

50. Spagnoletta, A.; De Palma, A.; Prezioso, G.; Scalera, V. A micro-batchwise technique method for rapid reconstitution of functionally active mitochondrial ADP/ATP carrier from Jerusalem artichoke (Helianthus tuberosus L.) tubers. J. Biochem. Biophys. Methods 2008, 70, 954-957. [CrossRef] [PubMed] 
51. Palmieri, F.; Indiveri, C.; Bisaccia, F.; Iacobazzi, V. Mitochondrial metabolite carrier proteins: Purification, reconstitution, and transport studies. Methods Enzymol. 1995, 260, 349-369. [CrossRef]

52. Laemmli, U.K. Cleavage of structural proteins during the assembly of the head of bacteriophage T4. Nature 1970, 227, 680-685. [CrossRef]

53. Morrissey, J.H. Silver stain for proteins in polyacrylamide gels: A modified procedure with enhanced uniform sensitivity. Anal. Biochem. 1981, 117, 307-310. [CrossRef]

54. Dulley, J.R.; Grieve, A.P. A simple technique for eliminating interference by detergents in the Lowry method of protein determination. Anal. Biochem. 1975, 64, 136-141. [CrossRef]

55. Sánchez, R.; Šali, A. Comparative Protein Structure Modeling: Introduction and Practical Examples with Modeller. In Protein Structure Prediction: Methods and Protocols; Webster, D.M., Ed.; Humana Press: Totowa, NJ, USA, 2000; pp. 97-129. [CrossRef]

56. Pebay-Peyroula, E.; Dahout-Gonzalez, C.; Kahn, R.; Trézéguet, V.; Lauquin, G.J.M.; Brandolin, G. Structure of Mitochondrial ADP / ATP Carrier in Complex with Carboxyatractyloside. Nature 2003, 426, 39-44. [CrossRef]

57. Vriend, G. WHAT IF: A Molecular Modeling and Drug Design Program. J. Mol. Graph. 1990, 8, 52-56. [CrossRef]

58. Curcio, R.; Muto, L.; Pierri, C.L.; Montalto, A.; Lauria, G.; Onofrio, A.; Fiorillo, M.; Fiermonte, G.; Lunetti, P.; Vozza, A.; et al. New Insights about the Structural Rearrangements Required for Substrate Translocation in the Bovine Mitochondrial Oxoglutarate Carrier. Biochim. Biophys. Acta Proteins Proteom. 2016, 1864, 1473-1480. [CrossRef] [PubMed]

59. Lauria, G.; Sanchez, P.; Morozzo Della Rocca, B.; Pierri, C.L.; Polizio, F.; Stipani, I.; Desideri, A. Structural-Dynamical Properties of the Transmembrane Segment VI of the Mitochondrial Oxoglutarate Carrier Studied by Site Directed Spin-Labeling. Mol. Membr. Biology. 2008, 25, 236-244. [CrossRef]

60. Sastry, G.M.; Adzhigirey, M.; Day, T.; Annabhimoju, R.; Sherman, W. Protein and ligand preparation: Parameters, protocols, and influence on virtual screening enrichments. J. Comput. Aid. Mol. Des. 2013, 27, 221-234. [CrossRef] [PubMed]

61. Groom, C.R.; Bruno, I.J.; Lightfoot, M.P.; Ward, S.C. The Cambridge Structural Database. Acta Cryst. B 2016, 72, 171-179. [CrossRef] [PubMed]

62. Koenig, D.F. The Structure of $\alpha$-Chlorohemin. Acta Cryst. 1965, 18, 663-673. [CrossRef] [PubMed]

63. Sherman, W.; Day, T.; Jacobson, M.P.; Friesner, R.A.; Farid, R. Novel Procedure for Modeling Ligand/Receptor Induced Fit Effects. J. Med. Chem. 2006, 49, 534-553. [CrossRef]

64. Friesner, R.A.; Banks, J.L.; Murphy, R.B.; Halgren, T.A.; Klicic, J.J.; Mainz, D.T.; Repasky, M.P.; Knoll, E.H.; Shelley, M.; Perry, J.K.; et al. Glide: A New Approach for Rapid, Accurate Docking and Scoring. 1. Method and Assessment of Docking Accuracy. J. Med. Chem. 2004, 47, 1739-1749. [CrossRef] [PubMed]

65. Harder, E.; Damm, W.; Maple, J.; Wu, C.; Reboul, M.; Xiang, J.Y.; Wang, L.; Lupyan, D.; Dahlgren, M.K.; Knight, J.L.; et al. OPLS3: A Force Field Providing Broad Coverage of Drug-like Small Molecules and Proteins. J. Chem. Theory. Comput. 2016, 12, 281-296. [CrossRef] [PubMed]

66. Klingenberg, M. Ligand-protein interaction in biomembrane carriers. The induced transition fit of transport catalysis. Biochemistry 2005, 21, 8563-8570. [CrossRef]

67. Das, D.; Tarafdar, P.K.; Chakrabarti, A. Structure-activity relationship of heme and its analogues in membrane damage and inhibition of fusion. FEBS Lett. 2018, 592, 2458-2465. [CrossRef] [PubMed]

68. Kunji, E.R.S.; Robinson, A.J. The conserved substrate binding site of mitochondrial carriers. Bioch. Bioph. Acta 2006, 1757, 1237-1248. [CrossRef]

69. Pietropaolo, A.; Pierri, C.L.; Palmieri, F.; Klingenberg, M. The switching mechanism of the mitochondrial ADP/ATP carrier explored by free-energy landscapes. Biochim. Biophys. Acta 2016, 1857, 772-781. [CrossRef]

70. Ruprecht, J.J.; King, M.S.; Zögg, T.; Aleksandrova, A.A.; Pardon, E.; Crichton, P.G.; Steyaert, J.; Kunji, E.R.S. The Molecular Mechanism of Transport by the Mitochondrial ADP/ATP Carrier. Cell 2019, 24, 435-447. [CrossRef]

71. Klingenberg, M. Transport viewed as a catalytic process. Biochimie 2007, 89, 1042-1048. [CrossRef]

72. Miller, Y.I.; Shaklai, N. Kinetics of hemin distribution in plasma reveals its role in lipoprotein oxidation. Biochim. Biophys. Acta. 1999, 1454, 153-164. [CrossRef]

73. Desautels, M.; Dulos, R.A. Hemin inhibits protein synthesis and degradation in isolated brown adipose tissue mitochondria. Can. J. Physiol. Pharmacol. 1994, 72, 970-978. [CrossRef] [PubMed]

74. Jiaxing, D.; Pei, W.; Shancai, X.; Yuchen, L.; Yishi, Z.; Ligang, W.; Chunlei, W.; Peiquan, Z.; Huaizhang, S. Changes in mitochondrial ultrastructure in SH-SY5Y cells during apoptosis induced by hemin. NeuroReport 2017, 28, 551-554. [CrossRef] 